\title{
The Potential for Facebook Application in Undergraduate Learning: A Study of Jordanian Students
}

\author{
Ayman Alarabiat \\ Information Systems and \\ Technology Department, \\ University of Minho, Portugal \\ sec@dsi.uminho.pt
}

\author{
Samer Al-Mohammad \\ Faculty of Business \\ Administration, \\ Mutah University, Jordan \\ samer f3@yahoo.com
}

\begin{abstract}
The purpose of this paper was to explore the current and potential use of Facebook for learning purposes by Jordanian university students. The paper attempted to compare such use with other uses of Facebook. Further, the paper investigated Jordanian university students' attitudes towards using Facebook as a formal academic tool, through the use of course-specific Facebook groups. To that end, quantitative data were collected from a sample of 451 students from three Jordanian public universities. Findings indicated that the vast majority of Jordanian students had Facebook accounts, which echoes its popularity amongst Jordanian youth compared to other types of online social networking sites. While both "social activities" and "entertainment" were the primary motivators for Jordanian students to create and use Facebook accounts, a growing number of them were using Facebook for academic purposes too. Further, Jordanian students had a positive attitude toward the use of "Facebook groups" as an educational tool for specific courses, and under specific conditions. Based on its findings, the paper provides suggestions for Jordanian higher institutions to invest in the application of Facebook as a formal academic tool.
\end{abstract}

Keywords: Facebook, social networks, academic context, purposes, uses, universities, Jordan.

\section{Introduction}

A social networking site (hereafter SNS) is defined as an internet-based service that gives individuals three major capabilities: first, the ability to construct a public or semi-public profile; second, the ability to identify a list of other users with whom a connection is shared; third, the ability to view and track individual connections as well as those made by others (Boyd \& Ellison, 2008).

Material published as part of this publication, either on-line or in print, is copyrighted by the Informing Science Institute. Permission to make digital or paper copy of part or all of these works for personal or classroom use is granted without fee provided that the copies are not made or distributed for profit or commercial advantage AND that copies 1) bear this notice in full and 2) give the full citation on the first page. It is permissible to abstract these works so long as credit is given. To copy in all other cases or to republish or to post on a server or to redistribute to lists requires specific permission and payment of a fee. Contact Publisher@,InformingScience.org to request redistribution permission.
Having managed to surpass its competitors within only five years of its launch in 2004, Facebook is currently the most popular SNS worldwide. According to recent figures released by the company itself, Facebook had over 1.3 billion active users as of June 2014. Approximately $82.2 \%$ of monthly active users are located outside the U.S. and Canada (Facebook Statictics, 2013.) According

Editor: June Lu

Submitted: Oct 25, 2014; Revised: Feb 12, March 15, and Apri2, 205I; Accepted: July 13, 2015 
to Arab Social Media Report (2014), the total number of Facebook users in the Arab world was approximately 81 million as of the beginning of May 2014, and the average for Facebook penetration in the Arab world was over 21.5\% in 2014, up from 15\% in 2013. According to the same report, $67 \%$ of Facebook users aged between 15-29 years. Such considerably high percentage of young Facebook users in the Arab world is due to the fact that Arab countries' populations are youthful in general (Arab Media Outlook, 2012). Young Arabs are facing many cultural, social, religious, and political constraints and restrictions. Driven by their human needs of selfpresentation, social interaction, freedom of speech and expression, and curiosity, Arab youth seek to liberate themselves from all kinds of restrictions to satisfy their needs through joining SNSs (Al Omoush, Yaseen \& Alma'aitah, 2012). In view of that, Facebook could be contributing to a greater revolution in Arabic young people's political, cultural and civic learning (Kassem, 2013).

In Jordan, 2.7 million Facebook users make up to 5\% of all Facebook users in the Arab world. With $39.2 \%$ of the population using Facebook, Jordan is the second among Arabic countries and considered "a high-penetration country" (Arab Social Media Report, 2014). Consistent with Arab world figures, recent research suggests that the majority of Jordanian undergraduate students, aged between 18- 24, are regularly using Facebook (e.g., Al Doghmi, Al-Shalabi, Jwaifel, Andraws, Awajan, \& Alrabea, 2013; Nassar, Hayajneh, \& Almsafir, 2013; Socialbakers, 2013). According to Socialbakers (2013) statistics, this particular age group represented the highest percentage (40\%) of Jordanian Facebook users in December, 2013. Such undeniable popularity of Facebook amongst Jordanian university students (Al-Debei, Al-Lozi, \& Papazafeiropoulou, 2013) drives this paper to raise a number of questions: To what purposes is Facebook used by Jordanian university students? To what extent is Facebook used for learning purposes by Jordanian university students? What is the potential for formal Facebook use in the learning process of Jordanian universities?

While traditional methods, such as tutorials and face-to-face lectures, are still strongly dominant in the Jordanian higher education arena (Al-Adwan, Al-Adwan \& Smedley, 2013), Jordanian universities are intensively investing in information and communication technologies to improve the quality of students' learning experience (Abu Qudais, Al-Adaileh \& Al-Omari, 2010; AlAdwan et al., 2013). While such technologies, like e-learning for example, require considerable investments, Facebook provides a substantially cost effective and popular alternative for Jordanian universities to enhance the learning experience they provide. Nevertheless, the mere availability of Facebook, or any other technological application, does not necessarily mean its success as an educational method. The favorable perceptions and attitudes of both students and tutors must also be there (Abu Qudais et al., 2010; Al-Adwan et al., 2013; Khasawneh \& Ibrahim, 2012).

Accordingly, this paper aims to explore the actual and potential use of Facebook by Jordanian university students for undergraduate learning. The paper attempts to compare such use with other uses of Facebook. Further, the paper attempts to explore students' attitudes towards using Facebook as a formal academic tool. More specifically, the paper attempts to achieve the following objectives:

- To explore Jordanian students' overall experience with Facebook and other SNSs.

- To understand students' original motivations/purposes for creating a Facebook account.

- To investigate if Facebook is being used, informally, for learning purposes.

- To explore students' perceptions towards using Facebook for formal academic purposes, especially towards using course-specific Facebook groups.

Our argument is that while education and learning are major responsibilities for any modern society and political regime, the application of such technologies in education should become a major 
concern. Thus, the results of this paper may contribute to persuading Jordanian students, faculties, and educational institutions to incorporate Facebook in academia.

The paper is divided into six sections. The second section reviews literature available on Facebook potential for, and application in, education. The third section underlines the methodology adopted for the empirical study of the paper. The fourth section highlights the major findings of the paper, while the fifth section discusses those findings. Finally, the sixth section underlines major limitations of our study and suggests future research avenues.

\section{Literature Review}

According to Nadkarni and Homann (2012), Facebook use is primarily determined by two basic social needs: (1) need to belong and (2) need for self-presentation. This social presence has the strongest impact on intention to use Facebook (Cheung, Chiu, \& Lee, 2011). Most people use Facebook to get instant communication and connection with their friends, in addition to entertainment value (Nadkarni \& Homann, 2012). Facebook provides various features and facilities that allow users to share, review, update, and edit different kinds of materials with others. It is the most popular online SNS among university students. Previous research shows that anywhere between $85 \%$ and $99 \%$ of university students use Facebook (Akyildiz \& Argan, 2012; Gafni \& Deri, 2012; Roblyer, McDaniel, Webb, Herman, \& Witty, 2010). Such high percentage raises some questions: What motivates students to use Facebook? How often do they use it, and for which activities?

A plethora of worldwide academic research has attempted to answer the above questions, most of which have shown similar findings and conclusions. Firstly, and with regard to motivations for using Facebook, social relationships were the most important motivation for use, followed by entertainment (Gafni \& Deri, 2012; Hussain, Gulrez, \& Tahirkheli, 2012; Moradabadi, Gharehshiran, \& Amrai, 2012). Secondly, and in relation to frequency of use, a large proportion of students used Facebook on daily basis or logged in several times a day (Hrastinski \& Aghaee, 2012; Hussain et al., 2012; Ruleman, 2012). The minimum time spent on site was 10 minutes, while the maximum time was 100 minutes (Kalpidou, Costin, \& Morris, 2011). Finally, and with regard to activities performed on Facebook, the most popular ones were viewing photos, commenting on content, and checking in to see what others are doing (Junco, 2012; Smith \& Caruso, 2010).

The popularity of Facebook has inspired numerous studies. The following literature review is organized into three sub-sections. The first one discusses two contradicting streams of research into Facebook application and potential in Undergraduate academic learning. The first stream of research explores a number of studies that yielded minimum support and application of Facebook in undergraduate learning. The second stream of research underlines and discusses a number of studies with more positive and favorable attitude and application of Facebook, and Facebook groups, in undergraduate learning. The studies discussed under both streams were organized chronologically and were chosen to represent different parts of the world. With regard to the second subsection of literature review, it attempts to address particular research conducted in Jordan on Facebook and other types of SNSs. The purpose is to emphasize the current situation of SNSs' academic application, if any, in Jordanian universities. Finally, the third subsection builds on discussion undertaken in previous two subsections to provide a logical rationale for this paper. It underlines the importance of this paper as an attempt to bridge the gap in current research addressing the potential for Facebook application in undergraduate learning in Jordan. 


\section{Facebook Use in Academia: Mixed Findings}

The potential impact of Facebook on students' motivation to learn has inspired researchers to examine the website's role in higher education. Surveying such studies has shown mixed results as to students' attitudes and willingness to use Facebook for academic purposes. For one stream of academic research, only a small portion of students used Facebook for academic purposes. For example, applying an online survey on a sample of first year undergraduates at one British university, Madge, Meek, Wellens, and Hooley (2009) found that $10 \%$ of 312 respondents used Facebook for discussing academic work with other students on daily basis, in comparison to $23 \%$ who made daily use of it to find out about social events. Additionally, $43 \%$ of sampled students responded negatively to the potential use of Facebook for academic purposes, explaining that Facebook was a SNS, not a tool for academic work. Madge et al. (2009) underlined that most of available research has focused on Anglo-American undergraduate students, who often remain a homogenized student body in research findings. They emphasized the need to study Facebook and other SNSs' uses in other international locales and regions, in order to cater for cultural, social, economic and political differences.

Similar findings to those of Madge et al. (2009) were reported by Pempek, Yermolayeva, and Calvert (2009). They underlined that $17 \%$ of 92 sampled American undergraduates used Facebook to communicate with each other for academic purposes. Having applied a descriptive approach to their study, Pempek et al. (2009) suggested that a more typical diary research approach may provide a broader measure of Facebook time use. Furthermore, and having conducted their study in a private university, Pempek et al. (2009) underlined that changing research locale/sample might yield different results. Analyzing Facebook "wall" activity of 909 undergraduates enrolled at one UK university, Selwyn (2009) reported similar finding to those of Pempek et al. (2009). Out of the 909 students sampled by Selwyn (2009), 612 students had accessible Facebook profiles. Selwyn (2009) analyzed 68,169 wall postings generated by those students over a period of 18 weeks. He found that only $4 \%$ of those postings were related to students' studies and academic experience. Despite its interesting approach and findings, Selwyn's (2009) study had a number of limitations such as non-generalizability and the fact that focusing on "wall" activities only has overlooked other communication options Facebook provides.

More recently, Haneefa and Sumitha (2011) reinforced previous findings, revealing that only $10.4 \%$ of 150 sampled Indian university students have considered SNSs as useful methods for academic communication. Having applied a quantitative descriptive approach to their study, a major limitation to the generalizability of Haneefa and Sumitha's (2011) findings was the fact that their study was conducted in one Indian university only. Another research with a case study methodology was conducted by Grosseck, Bran, and Tiru (2011) who declared that only $26.7 \%$ of the sampled first year Romanian students at one university perceived the use of Facebook and educational groups as important instruments of change in higher education. Focusing on engineering students enrolled at 4 Israeli institutions Gafni and Deri (2012) found that only $25 \%$ of 103 sampled students believed that Facebook helped them significantly in their studies, and that perceptions towards Facebook academic benefits differed according to academic years the respondents were in. Interestingly, and in addition to applying quantitative surveys, Gafni and Deri (2012) reviewed seven Facebook pages that belonged to different engineering institutions to check for significance of traffic and use of those pages. They suggested that formal Facebook pages developed by those institutions were not properly designed to enhance students' learning experience. Applying an online survey, Haytko and Parker (2012) found that a large percentage of 236 sampled students in two American universities (73.2\%) did not consider Facebook an appropriate method for professors to use in posting course information and communicating with students. They suggested that not all information technologies are appropriate for classroom use, and the latest fad may not present the best way to interact with current generation of students. 
Finally, after interviewing a sample of 20 Swedish university students, Hrastinski and Aghaee (2012) also found that only $25 \%$ of students referred to Facebook as a useful way for initiating communication to find classmates and group work members. However, few of them mentioned Facebook when discussing social media use for educational purposes. Instead, majority of the students $(85 \%)$ named other forms of electronic media such as e-mail, which was actually used to share documents by $70 \%$ of them. Having underlined the major limitation of their study, i.e., conducting a limited number of brief interviews, Hrastinski and Aghaee (2012) suggested that there was a need to understand how students use and would like to use social media to support their studies in different settings.

For the above stream of research, it appears that Facebook for students is first and foremost a social networking site; a tool to get away from study instead of actually doing school work; hence students tend to purposefully demarcate boundaries to keep these two aspects separate. On the other hand, another stream of research has underlined more positive attitudes and use of Facebook for academic purposes (DiVall \& Kirwin, 2012; Kayri \& Çakır, 2010; Mazman \& Usluel, 2010; Petrović, Petrović, Jeremić, Milenković, \& Cirović, 2012; Roblyer, McDaniel, Webb, \& Herman, 2010; Tiryakioglu \& Erzurum, 2011). Results of such research have shown that Facebook usage was not merely social. There was an academic use of Facebook by students in terms of sharing learning experiences and research findings, sharing academic events over the site, and getting latest information related to their studies.

For instance, after surveying a sample of 182 faculty members and students at an American university, Roblyer et al. (2010) indicated that $46.7 \%$ of the respondents believed that using Facebook for class work-related purposes of any kind would be convenient, and only $22.5 \%$ said that Facebook is personal/social and not for education. They declared that, despite the fact that the results of their study provided limited and tentative evidence, due to the fact that it was conducted in one university, Facebook remains a trend worth watching and tracking with future research "snapshots". Further, Karl and Peluchette (2011) found that 53\% of 208 surveyed American undergraduates were positive about the use of Facebook for teaching and learning as long as the focus was on administrative matters such as queries and lecture notes. In addition, Hussain et al. (2012) found that $76 \%$ of the 600 students sampled in one Pakistani university used social media, including Facebook, for sharing their learning experiences and research findings, 59\% shared academic events over the media, and $92 \%$ used it for getting latest information related with their studies. Hussain et al. suggested that proper training might be required for students' proper use of social media.

In line with the above stream of research, many empirical findings have underlined the positive impact of educational Facebook "groups" over students' attitudes towards, and use of, Facebook for academic purposes. For example, Kayri and Çakır (2010) conducted a three-month research focusing on a study group which consisted of 58 Turkish students coming from two different universities. The analysis of their semi-experimental approach revealed positive students' attitudes towards educational use of Facebook groups. Furthermore, Al-Atabi and Younis (2010) created a course-specific Facebook group for a certain module introduced to first year students at a Malaysian university. Their findings confirmed that $80 \%$ of the 66 sampled students liked the idea of using Facebook for learning and considered it as a useful experience. The number of students joining the experimental Facebook group grew steadily throughout the semester; about $90 \%$ joined the Facebook group by the end of semester, compared to the $60 \%$ who joined at the beginning. In the same vein, Liu (2010) found that $47 \%$ of the 221 students surveyed online, in two American communication and business schools, preferred course-specific groups with no membership required, $36 \%$ preferred groups based on contemporary topics that may not last long, and $27 \%$ of them liked to join groups with protected membership. Interestingly, Liu's (2010) sample was a mixture of both undergraduate and graduate students. She emphasized that the future tech- 
nology integration in education should focus on what students use instead of what the school wants them to use to guarantee maximum efficiency.

More recently, and in an experimental study conducted by DiVall and Kirwin (2012), a Coursespecific Facebook page was created at one American University. Students who took the course were encouraged to "like" the page and to post and view study tips, links, or questions. At the end of the course, students' use and perceptions were evaluated using an anonymous survey tool. DiVall and Kirwin (2012) confirmed that $86 \%$ of the 119 students who completed the survey found Facebook academic pages beneficial overall; they reported Facebook academic pages as valuable and helpful study tools, further, $57 \%$ said they would miss the posts when the course ended. They suggested that faculty members should have an open discussion of the benefits, workload implications, and possible risks of course-specific Facebook groups for students and course instructors. More evidence was also offered by Petrović et al. (2012), who implemented a course- specific Facebook group experiment on a sample of 68 final year students attending a specific course at one Serbian university. According to Petrović et al. (2012), a majority of the participants (97.7\%) considered that the use of Facebook groups had significantly increased their knowledge; about ninety five percent of them were more motivated to participate in the process of learning. Despite the interesting findings of the four previous studies, they all suffered the limitations associated with experimental designs, such as non-generalizability and inability to control certain factors in real life context.

\section{The use of Facebook by Jordanian university students: Reasons and applications}

The wide spread use of SNSs, especially Facebook, by Jordanian youth has sparked considerable academic research, particularly in Jordanian universities context (e.g., Abu Husein, Al-Sukkar, Salah, \& Jaradat, 2013; Abu-Shanab \& Al-Tarawneh, 2013; Al Doghmi et al., 2013; Al-Debei et al., 2013; Al-Saleem, 2011; Gasaymeh \& Jwaifell, 2013; Jwaifell, Al-Shalabi, Andraws, Awajan, \& Alrabea, 2013; Nassar et al., 2013; Swidan, Al-Shalabi, Jwaifell, Awajan, \& Alrabea, 2013). According to such research, Jordanian university students used SNSs because they provided them with the chance to freely express their opinions, develop personal skills and interact with others (Abu Husein et al., 2013). To Jordanian students, SNSs represented easy-to-use, easy-to-learn mediums to improve communications between people on equal terms (Nassar et al., 2013; Swidan et al., 2013). Further, academic research revealed that Jordanian university students used SNSs for various purposes, including; social, religious, and political discussions, getting more information, finding old and new friends, entertainment, and education (Abu Husein et al., 2013; Abu-Shanab \& Al-Tarawneh, 2013).

The use and benefits of SNSs for academic purposes in Jordan seems to be an area of particular interest for some researchers. For instance, Gasaymeh and Jwaifell (2013) examined Jordanian undergraduate students' attitudes toward using weblogs into their learning course. They followed a mixed design in their study: questionnaires, weblog analysis, and semi-structured interviews. Study participants were 24 students enrolled in one class at one Jordanian university. Despite the small and convenient sample, Gasaymeh and Jwaifell (2013) revealed that students had positive attitudes toward the use of a weblog as a tool for communication and education. Another study by Al Doghmi et al. (2013) aimed at exploring the academic uses of SNSs among students in four Jordanian universities. Their survey results, of 727 sampled students, showed that respondents were using SNSs both intensively and informally for academic and group-building purposes. Al Doghmi et al (2013) claimed that Jordanian students were ready and willing to use SNSs as a communication tools for academic purposes. Accordingly, they recommended that SNSs should be integrated in university learning management systems. Finally, a study by Jwaifell et al. (2013) aimed at investigating the intensity of SNSs uses among Jordanian university students. Applying 
a survey design in four Jordanian universities, Jwaifell et al. (2013) suggested that SNSs can be formally used as an academic tool for communication and interaction between students or with educators alike. They called for academics and policy makers to take advantage of SNSs through incorporating them into higher education.

\section{Rationale behind paper}

A careful review of worldwide and local research on Facebook's potential application in university learning has yielded a number of interesting observations. Firstly, a consensus has yet to emerge as to whether Facebook can be successfully applied in university learning. This might be due to the fact that different research has been conducted in different countries with highly varied cultural, social, economic, and political circumstances. Secondly, in addition to the fact that research on Facebook's academic application has been conducted in different countries and locales, different types of empirical methods were applied, e.g., case studies, surveys, experiments, interviews. While such methodologies have their advantages, they are all prone to some weaknesses too.

Thirdly, different types of respondents were addressed in those studies. For example some studies focused on tutors and students, while others focused solely on students. Some of the studies that focused on students have actually focused on students in certain academic levels/years, while others focused on students of all academic levels/years. Some studies have addressed students in general, while others have focused on students attending certain academic courses. Accordingly, there seems to be no universal sampling approach followed. Fourthly, research conducted in Jordan has focused on SNSs' applications for academic purposes in general, not on particular types of SNSs such as Facebook. While the results of such research are interesting and valuable, they lack specification and ability to generalize due to the fact that while SNSs share similar purposes, they do differ in terms of technical functions and methods of use.

Based on the above observations, and in relation to some of the arguments underlined in literature review, research into the application of Facebook for academic purposes remains an area worthy of further examination and study, especially in different research contexts. In the Jordanian context, there is a call for applying Facebook and other SNSs for university learning purposes (Al Doghmi et al., 2013; Jwaifell et al., 2013). This paper adopts Lui's (2010) argument that a good starting point for an effective integration of Facebook in university learning is to understand students' actual uses of it, and their perceptions and attitudes towards using it in learning. Accordingly, this paper attempts to explore university students' use(s) of Facebook, and their attitudes towards using it for academic learning in particular. The high penetration rate of Facebook amongst Jordanian youth in general, and university students in particular, makes this paper worthwhile. The results of this paper might provide general insights into the potential value of formal application of Facebook in university learning process.

\section{Methodology}

\section{Population and Sample}

According to Ministry of Higher Education statistics (2013), the total number of Jordanian students in the country's 10 public universities was 197,823 . The sample of this study consisted of 85,448 students of three major Jordanian public universities. Those universities were chosen for three reasons. Firstly, the total number of students in those three universities represented approximately $43 \%$ of students attending Jordanian public universities. Secondly, the three universities were geographically located in the middle of Jordan, where more than half the population is located. Thirdly, the three universities had a diverse range of majors categorized under several faculties. Accordingly, those universities provided a suitable locale for empirical research. Based on 
Sekaran and Bougie's (2010) sample size guidelines, and applying an online sample calculator (i.e., http://www.surveysystem.com/sscalc.htm), a sample size of 383 respondents was deemed appropriate for empirical research purposes. Accordingly, and to cater for non-response concerns, 500 questionnaires were distributed in the three chosen universities. Out of the 472 returned questionnaires, 21 incomplete questionnaires were excluded. The resulting, usable, 451 questionnaires were divided as follows: 207 questionnaires came from the first university, 115 from the second university, and 129 from the third university.

\section{Measurement Items and Validity}

Survey items were adapted from previous studies (Appendix). The validity of the questionnaire was confirmed through two referees (assistance professors in MIS department at one Jordanian university) to judge items' appropriateness for measuring intended research questions and to decide if the statements were understandable. Based on feedback received from the referees, the scale was modified and tested on 20 students from the population universities; those students were removed from the sample. Results of the pilot study were used to refine the survey instrument (questionnaire) and to clarify any difficult-to-understand items. The final questionnaire consisted of three sections: demographic questions, questions about students' experiences with Facebook, and students' perceptions and attitudes towards course-specific "Facebook groups". Different types of questions were applied in the questionnaire: closed -ended questions, multiple choice ones, and five-point "Likert scale" type questions.

\section{Data Analysis and Reliability}

In order to achieve the paper's exploratory objectives, descriptive data analysis was conducted, using SPSS 18 package. Both "Mean" and "Standard Deviation" were computed for descriptive data analysis. Consistent with Ababneh (2008), and based on statements' mean scores, levels of agreement were divided into three categories: a mean value of 1.00 to 2.49 indicated a low level of agreement, a mean value of 2.50 to 3.49 indicated a moderate level of agreement, and a mean value of 3.50 to 5.00 indicated a high level of agreement. Furthermore, percentages were used to better describe and compare respondents' characteristics, attitudes and behaviors. With regard to reliability of measurement items, Cronbach alpha test was applied to measure the internal consistency reliability of the overall measure. Overall reliability was 0.87 which was considered to be very satisfactory (Sekaran \& Bougie, 2010). Cronbach alpha for study variables ranged from 0.66 to 0.85 , indicating a satisfactory level of reliability.

\section{Sample Characteristics}

Detailed respondents' characteristics are shown in Table 1 . The table shows that $59 \%$ of respondents were females $(n=266)$ while $41 \%$ were males $(n=185)$. According to Assi $(2011), 63 \%$ of university students in Jordan were females. While Assi (2011) was referring to female representation in all Jordanian universities, the slightly lower percentage of females represented in this paper's sample could be due to the fact that respondents came from three Jordanian universities only. Over half of the sample's respondents $(53.7 \%)$ came from Social Sciences \& Humanities schools, followed by those from Sciences and Technologies schools (39.0\%). Respondents from medical schools were the fewest $(7.30 \%)$. The distribution of respondents among the three schools was deemed logical considering that, in Jordan, Social Sciences \& Humanities usually have the highest numbers of students, followed by schools of Sciences and Technologies and Medical ones. With regard to their level of study, $30.4 \%$ of respondents were in their first year, almost half of the respondents were in their second and third years, while only $1.80 \%$ of them were in their fourth year. Finally, 55.4\% of the respondents had a GPA of 2.34 to 3.33, with 
$13.3 \%$ of them in the "top" range of 3.34 to 4.00 , and only $2.22 \%$ of the respondents in the lowest 1.00 to 1.33 .

\begin{tabular}{|c|c|c|c|}
\hline \multicolumn{4}{|c|}{ Table 1: Sample demographics } \\
\hline $\begin{array}{l}\text { DEMOGRAPHIC } \\
\text { VARIABLE }\end{array}$ & ITEM & FREQUENCY & $\begin{array}{c}\text { PERCENTAGE } \\
(\%)\end{array}$ \\
\hline \multirow[t]{2}{*}{ Gender } & Male & 185 & 41.0 \\
\hline & Female & 266 & 59.0 \\
\hline \multirow[t]{3}{*}{ School } & $\begin{array}{l}\text { Social Sciences \& } \\
\text { Humanities }\end{array}$ & 242 & 53.7 \\
\hline & $\begin{array}{l}\text { Sciences \& Technolo- } \\
\text { gies }\end{array}$ & 176 & 39.0 \\
\hline & Medical & 33 & 7.30 \\
\hline \multirow[t]{4}{*}{ Level of Study } & First year & 137 & 30.4 \\
\hline & Second year & 121 & 26.8 \\
\hline & Third year & 111 & 24.6 \\
\hline & Fourth year & 74 & 16.4 \\
\hline \multirow[t]{4}{*}{ GPA } & A, A- & 60 & 13.3 \\
\hline & $\mathbf{B}+, \mathbf{B}, \mathbf{B}-$ & 250 & 55.4 \\
\hline & $\mathrm{C}+, \mathrm{C}, \mathrm{C}-$ & 131 & 29.1 \\
\hline & $\mathbf{D}, \mathbf{D}+$ & 10 & 2.20 \\
\hline
\end{tabular}

\section{Descriptive Results}

As underlined earlier, descriptive statistics were deemed suitable for the exploratory nature of this paper. The following sub-sections were designed to address each of the paper's assigned objectives, namely:

- To explore Jordanian students' overall experience with Facebook and other SNSs.

- To understand students' original motivations/purposes for creating a Facebook account.

- To investigate if Facebook is being used, informally, for learning purposes.

- To explore students' perceptions towards using Facebook for formal academic purposes, especially towards using course-specific Facebook groups.

Figures and tables were applied to provide better expression of means and percentages describing sample respondents' attitudes and behaviors. 


\section{Facebook Experience}

Consistent with previous research findings in the same context (e.g., Alexa, 2013; Socialbakers, 2013), Figure 1 indicates that the vast majority of the Jordanian students (95.6\%) had Facebook accounts. Seventy seven percent of students had only one account, while only $4.4 \%$ of them reported that they did not have any Facebook account at all. With regard to Facebook membership duration, Figure 2 underlines that less than one third of the students $(32.7 \%)$ had maintained a Facebook account for more than 4 years, and nearly $43.9 \%$ of them had kept an account for $2-4$ years.

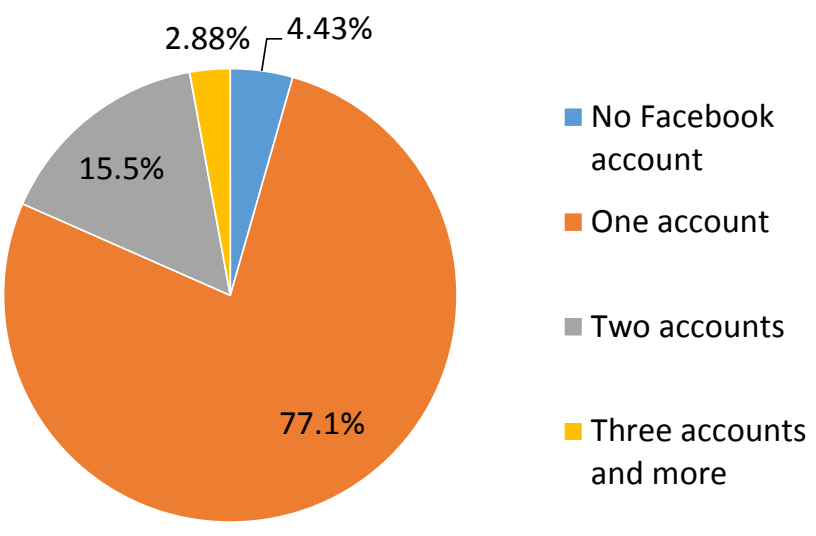

Figure 1: Number of Students' FB Accounts

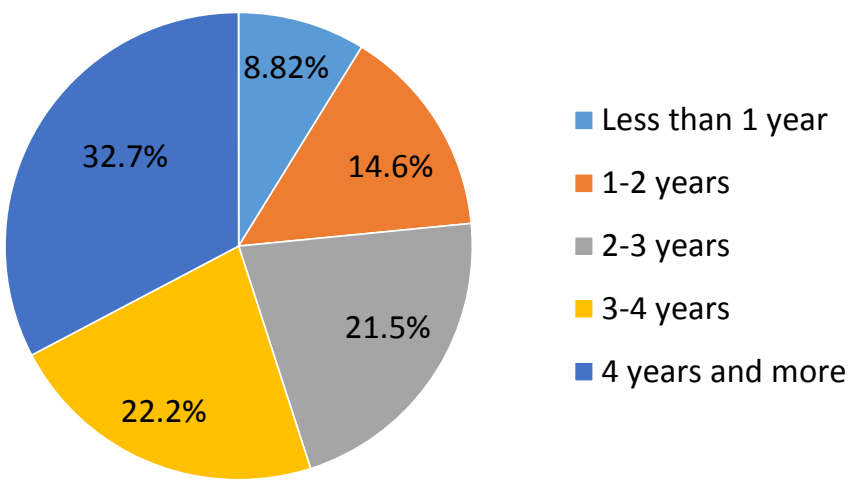

Figure 2: Students' FB Membership

With regard to time spent on Facebook, Figure 3 shows that the greatest part of students $(83.3 \%)$ logged on to Facebook on a daily basis, while $38 \%$ of them checked their accounts more than five times a day. Consistent with previous empirical findings (e.g., Akyıldı \& Argan, 2012;

Hrastinski \& Aghaee, 2012; Hussain et al., 2012; Junco, 2012; Kalpidou et al., 2011; Nassar et al., 2013; Ruleman, 2012) approximately half of the students with Facebook accounts were spending between 60 minutes to more than 120 minutes per visit. The students' length of stay on Facebook is shown in Figure 4. 


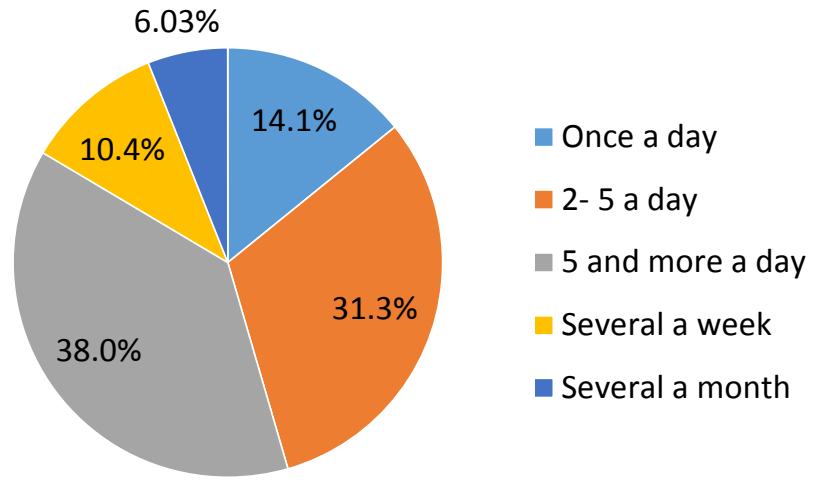

Figure 3: Frequency of Students' visit to their FB Accounts

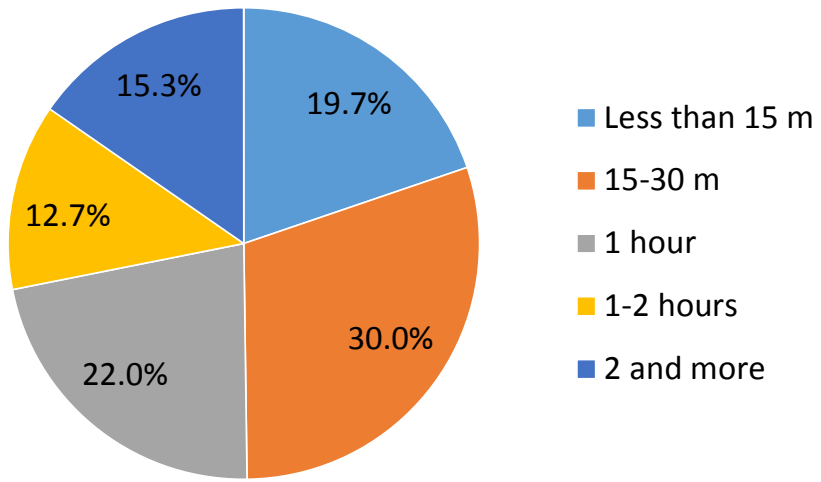

Figure 4: Students' length of stay on FB

With regard to students' use of other SNSs, Figure 5 shows that majority of the students $(77 \%)$ had another SNSs account; $26 \%$ of them had an account on Twitter, $25 \%$ on Youtube, and 14\% on Google Plus, $2 \%$ had LinkedIn accounts. In addition, $4 \%$ of the students used WhatsApp application. 


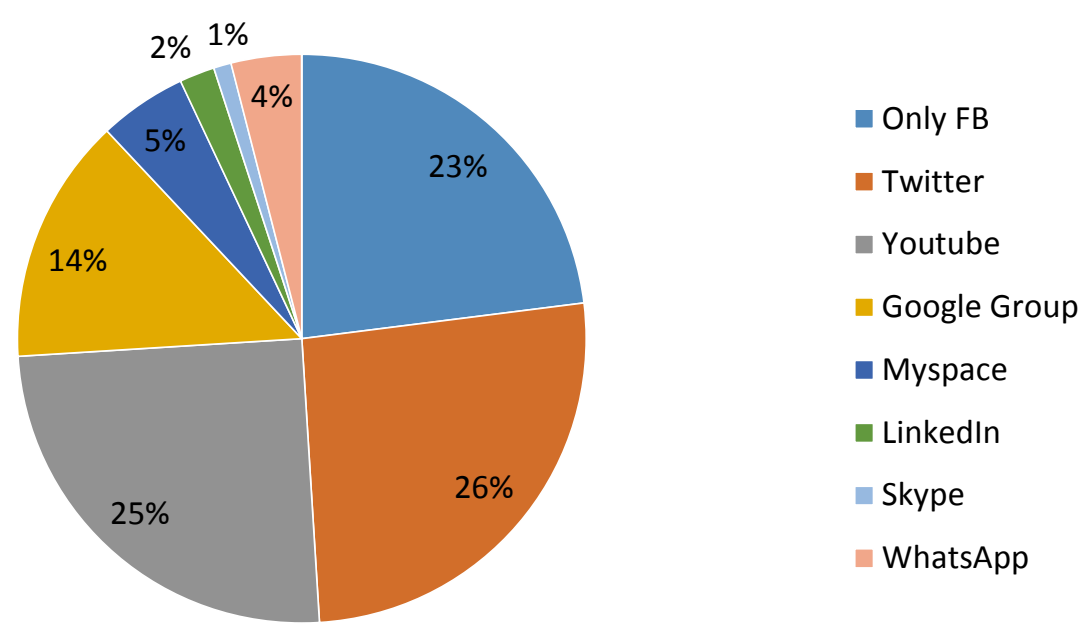

Figure 5: Other Social network sites membership

\section{Motivations for Using Facebook}

Mean scores were calculated and used to determine students' motivations for using Facebook. In relation to the "Data Analysis and Reliability" subsection, responses were categorized as follows: a mean value of 1.00 to 2.49 indicated an unimportant/weak motivation, a mean value of 2.50 to 3.49 indicated a moderate motivation, and a mean value of 3.50 to 5.00 indicated a high/strong motivation. Table 2 shows respondents' reasons for using Facebook arranged from the strongest to the weakest by arithmetic mean. As shown in Table 2, mean value of the first three reasons ranged from 3.50 to 5.00. Thus, these reasons presented strong motivations for creating and using Facebook account, namely; "staying in touch with friends and family" $(\mathrm{M}=3.95$, std=1.07) as the strongest reason, "entertainment, having fun and wasting time" $(\mathrm{M}=3.80, \mathrm{std}=1.11)$ as the second strongest, and "general academic purposes" $(\mathrm{M}=3.62$, $\mathrm{std}=1.15)$ as the third strongest. The mean value for the next five reasons ranged from 2.50 to 3.49; hence, the level of agreement with the statements measuring these reasons was moderate. Those reasons were "meeting new people and making new relationships" $(\mathrm{M}=3.22$, std=1.19)," self-presentation and letting others know what is happening in my life" $(\mathrm{M}=3.18$, std=1.14), " supporting worthy causes such as political, environmental, religious, national, or medical" $(\mathrm{M}=2.93$, std=1.20), "freedom to express opinions and views" $(\mathrm{M}=2.76$, std=1.25), and "meeting or forming a relationship with opposite gender" $(\mathrm{M}=2.66, \mathrm{std}=1.28)$. Interestingly, as Table 2 underlines, no reason was categorized as low.

\section{Facebook Use for Academic Purposes}

With regard to students' particular use of Facebook for academic purposes, Figure 6 underlines that approximately $72 \%$ of students who had Facebook accounts have actually used Facebook for academic purposes such as discussing, collaborating, and getting help about courses and lectures (values 3, 4, and 5 in Figure 6). However, and despite such high percentage, only $17.5 \%$ of students reported that they frequently used Facebook for academic matters. On the other hand, nearly $28 \%$ of them had seldom or never used Facebook for such issues (values 1 and 2 in Figure 6). 


\begin{tabular}{|l|c|c|c|}
\hline \multicolumn{4}{|c|}{ Table 2: Mean and Standard deviation for students' reasons } \\
to create a Facebook account \\
\hline \multicolumn{1}{|c|}{ STATEMENT } & MEAN & $\begin{array}{c}\text { STD. DEVI- } \\
\text { ATION }\end{array}$ & CATEGORY \\
\hline $\begin{array}{l}\text { Staying in touch with my friends/family and } \\
\text { connecting with people I have lost touch with }\end{array}$ & 3.95 & 1.07 & High \\
\hline Entertainment, having fun and wasting time & 3.80 & 1.11 & High \\
\hline $\begin{array}{l}\text { General academic purposes(such as sharing } \\
\text { information about my courses) }\end{array}$ & 3.62 & 1.15 & High \\
\hline $\begin{array}{l}\text { Meeting new people and making new } \\
\text { relationships }\end{array}$ & 3.22 & 1.19 & Moderate \\
\hline $\begin{array}{l}\text { Self-presentation and letting others know what is } \\
\text { happening in my life }\end{array}$ & 3.18 & 1.14 & Moderate \\
\hline $\begin{array}{l}\text { Supporting worthy causes (political, } \\
\text { environmental, religious, national, medical, etc.) }\end{array}$ & 2.93 & 1.20 & Moderate \\
\hline $\begin{array}{l}\text { Expressing my opinions and views } \\
\text { since I can say on Facebook what I can't in } \\
\text { person }\end{array}$ & 2.76 & 1.25 & Moderate \\
\hline $\begin{array}{l}\text { Meeting or forming relationship with opposite } \\
\text { gender (not necessarily romantic) }\end{array}$ & 2.66 & 1.28 & Moderate \\
\hline
\end{tabular}

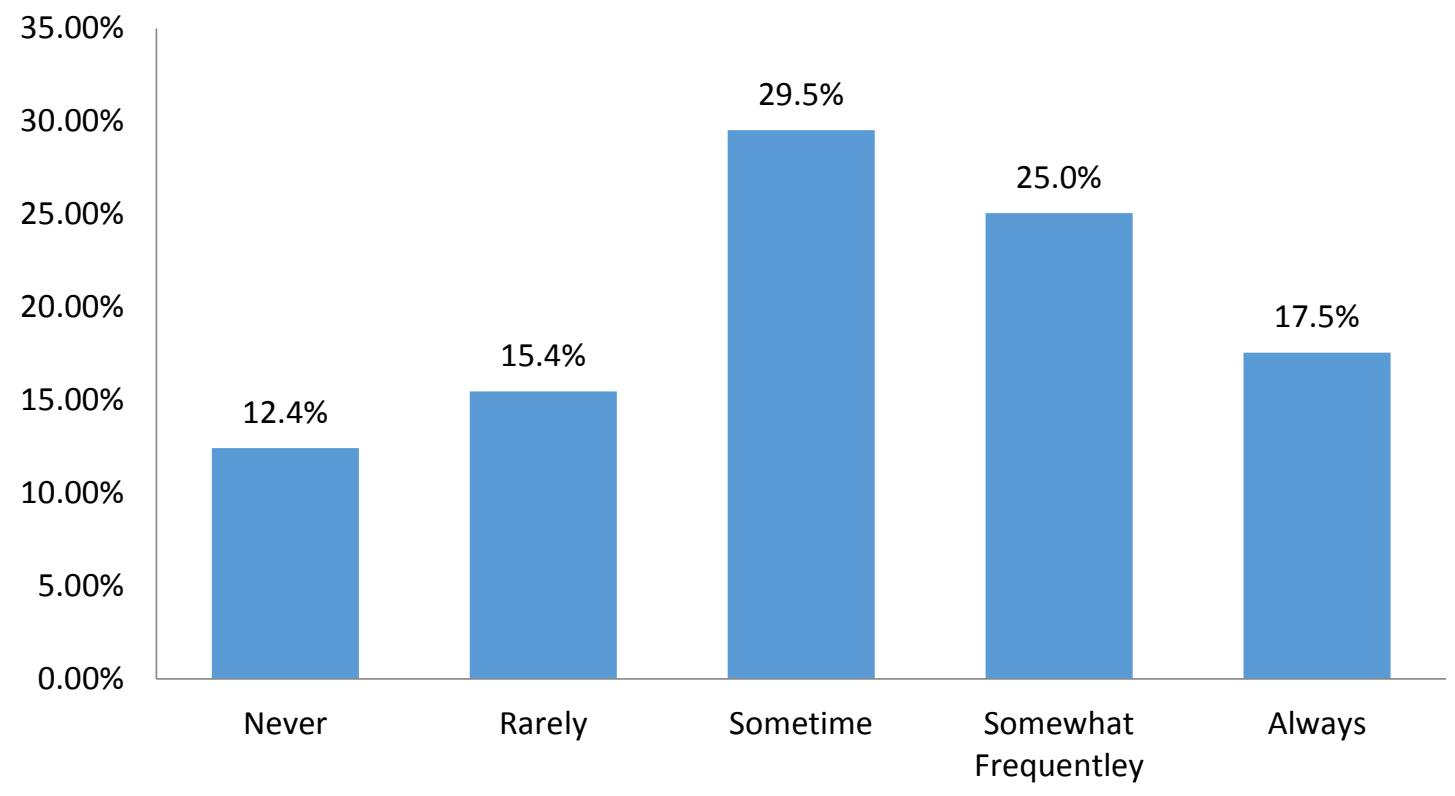

Figure 6: Frequencies of students' use of Facebook for academic purposes 


\section{Attitudes towards the Use of Course-Specific "Facebook Groups"}

With regard to students' perceptions about "formal" academic uses of Facebook, such as creating official university's Facebook pages or creating course-specific "Facebook groups", Figure 7 shows that the majority of the students $(86.8 \%)$ considered Facebook as a good method to be used for academic purposes, with $40.5 \%$ of them feeling that this method should be offered in a limited and suitable way. On the other hand, a small percentage of students $(13.3 \%)$ have underlined that they did not want to use Facebook for anything related to their studies, and they still considered Facebook as a social network not suitable for education.

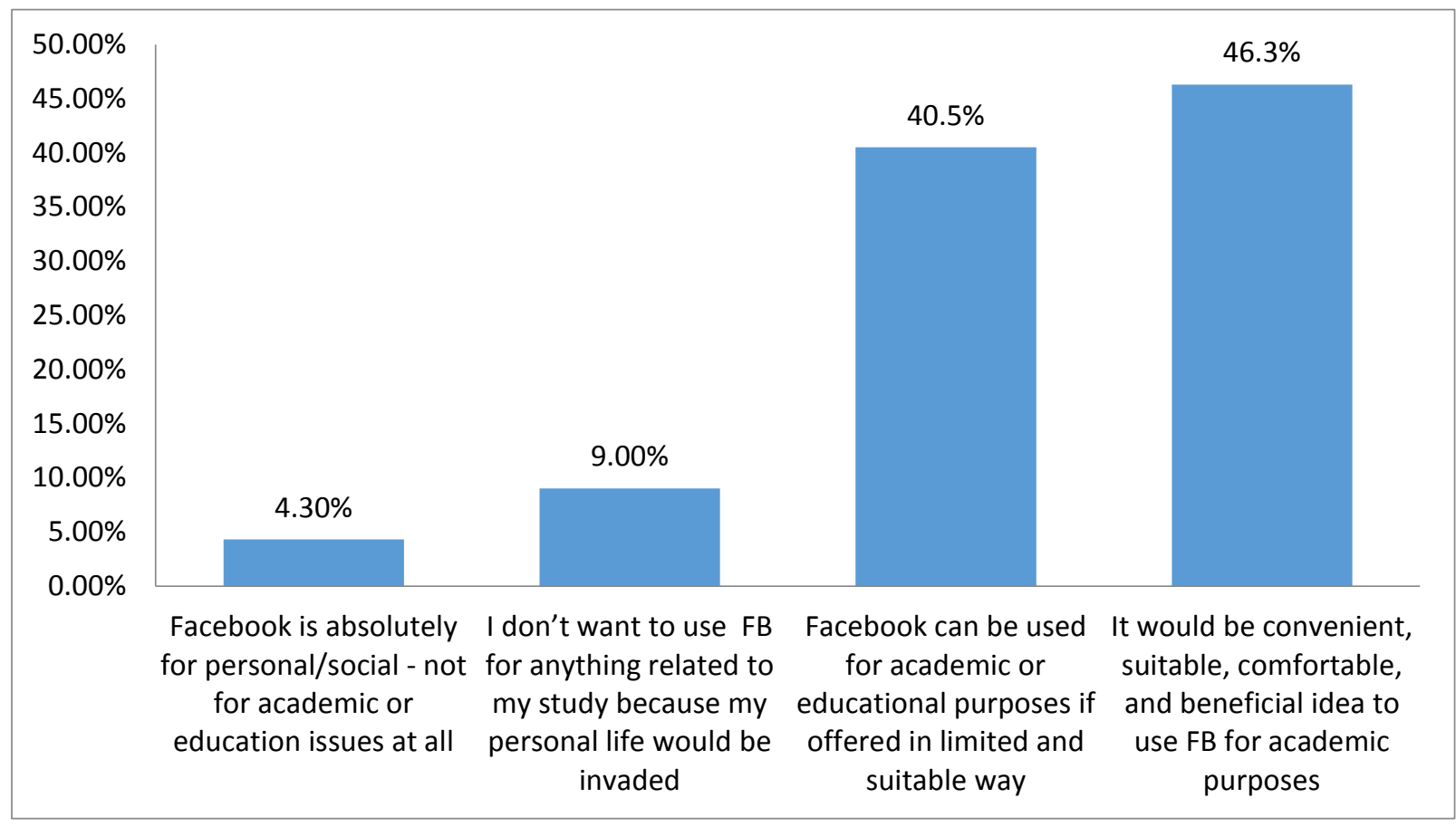

Figure 7: Students' perception on Facebook for academic purposes

Table 3 demonstrates students' perceptions and attitudes towards using formal "Facebook groups" as an educational tool for specific courses. Participants' responses were scored on a 5point Likert Scale ranging from "Strongly Disagree" (1.00) to "Strongly Agree" (5.00). Descriptive analysis was conducted estimating the means for each response and used to determine the importance of each statement, responses were categorized as "high agreement" (3.50 to5.00), "moderate agreement" (2.50 to 3.49), and "low agreement" (1.00 to 2.49). As indicated by Table 3 , the level of overall agreement with all items measuring students' attitudes toward coursespecific "Facebook groups" was high $(\mathrm{M}=3.58, \mathrm{std}=1.07)$. Out of 14 survey items, 11 fell under "high agreement", 2 had "moderate agreement", while only one item had "low agreement". The item with the highest agreement was: "Facebook group would break barriers among students" $(\mathrm{M}=3.92, \mathrm{std}=1.01)$. On the other hand, "using separate accounts for academic groups" $(\mathrm{M}=2.44$, std $=1.25$ ) was the item with the lowest level of agreement. 


\begin{tabular}{|c|c|c|c|}
\hline STATEMENT & MEAN & $\begin{array}{l}\text { STD. DE- } \\
\text { VIATION }\end{array}$ & $\begin{array}{l}\text { CATE- } \\
\text { GORY }\end{array}$ \\
\hline $\begin{array}{l}\text { It's a good idea to create closed Facebook group to share } \\
\text { course material such as assignment, study tips, questions, } \\
\text { etc.... }\end{array}$ & 3.55 & 1.11 & High \\
\hline $\begin{array}{l}\text { Facebook groups, in general, are useful method for } \\
\text { academic and educational purposes }\end{array}$ & 3.64 & 1.01 & High \\
\hline $\begin{array}{l}\text { An academic group is a comfortable learning method } \\
\text { because it is not necessary for me to become a "friend" of } \\
\text { lecturers or class students }\end{array}$ & 3.48 & 1.01 & Moderate \\
\hline $\begin{array}{l}\text { Facebook familiarity, and frequently use, could encourage } \\
\text { students to join and discuss learning material on specific } \\
\text { Facebook groups }\end{array}$ & 3.75 & 0.93 & High \\
\hline $\begin{array}{l}\text { I will create a separate Facebook account for my courses, } \\
\text { because I don't like my lecturers or my class mates to see } \\
\text { my original profile. }\end{array}$ & 2.44 & 1.25 & Low \\
\hline $\begin{array}{l}\text { Joining "specific-course Facebook group" should be } \\
\text { voluntary. }\end{array}$ & 3.76 & 1.02 & High \\
\hline $\begin{array}{l}\text { A Facebook group is a convenient mean to facilitate } \\
\text { student engagement and participation in teamwork }\end{array}$ & 3.68 & 0.99 & High \\
\hline $\begin{array}{l}\text { Group administration should be left basically with the } \\
\text { students, lecturers interferences should be for committing } \\
\text { or adding relative links or topics. }\end{array}$ & 3.52 & 1.09 & High \\
\hline $\begin{array}{l}\text { A Facebook learning group should be just an academic } \\
\text { group }\end{array}$ & 3.56 & 1.11 & High \\
\hline $\begin{array}{l}\text { A Facebook learning group could break barriers for those } \\
\text { who are shy to find help, and it could encourage students } \\
\text { to freely ask questions and peak }\end{array}$ & 3.92 & 1.01 & High \\
\hline $\begin{array}{l}\text { In a Facebook group, tutors can get more feedback than in } \\
\text { traditional class situations, where a few students may } \\
\text { participate. }\end{array}$ & 3.85 & 1.01 & High \\
\hline $\begin{array}{l}\text { An academic Facebook group could be valuable for me, } \\
\text { saving my effort and time }\end{array}$ & 3.74 & 1.05 & High \\
\hline $\begin{array}{l}\text { I intend to join course- specific Facebook groups for my } \\
\text { courses if applied }\end{array}$ & 3.69 & 1.11 & High \\
\hline $\begin{array}{l}\text { My grades would be better if I participated in course- } \\
\text { specific Facebook groups }\end{array}$ & 3.27 & 1.26 & Moderate \\
\hline All variables & 3.58 & 1.07 & High \\
\hline
\end{tabular}

According to Table 3, students highly accommodated the idea of creating course-specific Facebook groups to share and discuss course materials $(\mathrm{M}=3.55$, $\mathrm{std}=1.11)$; they further provided a strong support to the argument that a course-specific Facebook group would be a useful and ap- 
plicable method for educational purposes $(\mathrm{M}=3.64$, $\mathrm{std}=1.01)$; and a suitable platform to facilitate students engagement and teamwork $(\mathrm{M}=3.68$, std $=0.99)$. Students strongly agreed that a course-specific Facebook group could save time and effort in their studies $(\mathrm{M}=3.74$, std=1.05), and it might help to break barriers and obtain more feedback $(\mathrm{M}=3.92$, std $=1.01 ; \mathrm{M}=3.85$, std=1.01). They also showed a relatively high preference to joining course-specific Facebook groups $(\mathrm{M}=3.69$, std=1.11), and to keeping such groups only for academic purposes $(\mathrm{M}=3.56$, std $=1.11$ ). Figure 8 shows that almost $85 \%$ of students expressed their intentions to join coursespecific Facebook groups.

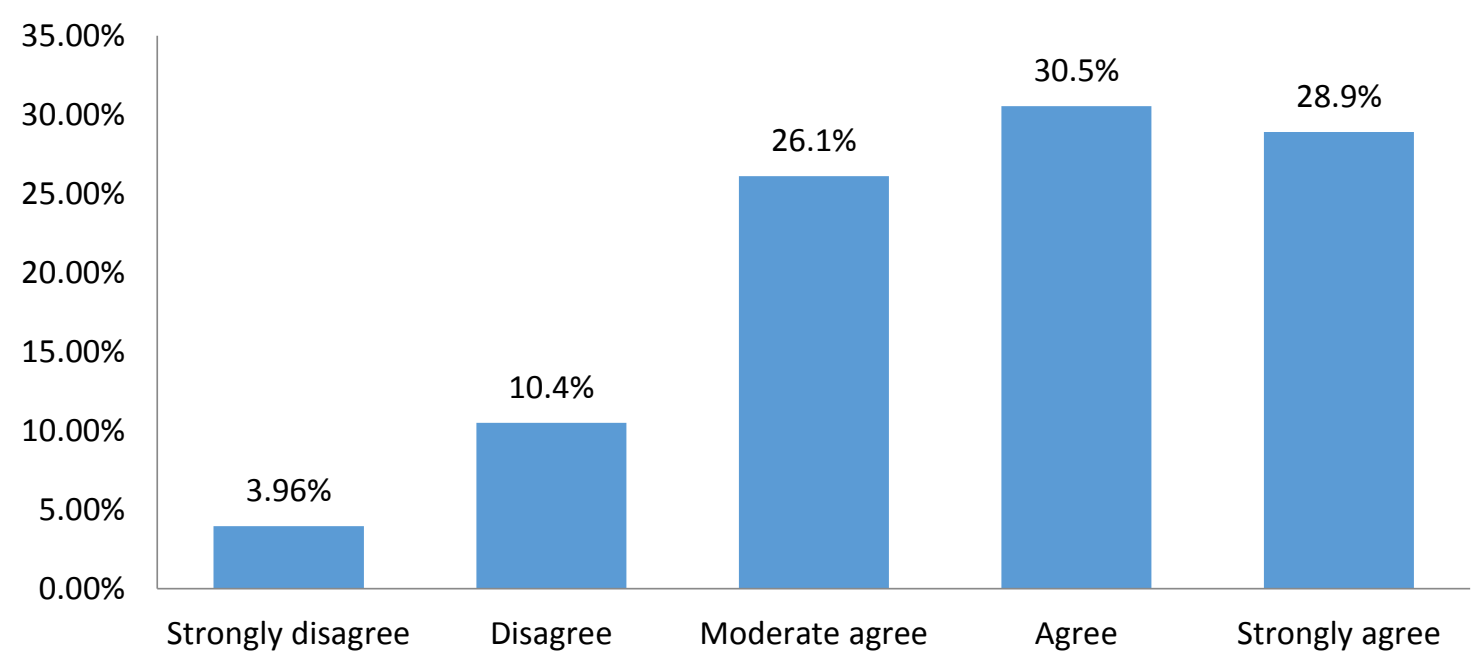

Figure 8: Students' intention to use Facebook for academic purposes

Nevertheless, despite such high agreement with previous arguments, Table 3 shows that students' agreement with the suggestion that participating in course-specific Facebook groups could improve their academic performance and grades was moderate $(\mathrm{M}=3.27$, std=1.26). Students further showed a moderate agreement to the suggestion that course-specific Facebook groups were a comfortable method to study since they wouldn't oblige them to become friends with their lecturers and other class students $(\mathrm{M}=3.48, \mathrm{std}=1.01)$. In fact, they did not agree with the suggestion that they would create a separate course specific Facebook account in order not to share original personal account with lecturers and fellow students $(\mathrm{M}=2.44$, $\mathrm{std}=1.25)$.

\section{Discussion and Conclusions:}

Amongst several SNSs available to Jordanian university students, Facebook remains, by far, the most popular. Similar to research findings in other contexts and parts of the world (e.g., Aky1ldiz \& Argan, 2012; Hrastinski \& Aghaee, 2012; Ruleman, 2012), Facebook has become part of Jordanian students' lives, which consumes a considerable amount of their daily time. Most of sampled Jordanian students logon to Facebook on daily basis, with some of them logging on several times a day. Generally, students spend between 15 to 60 minutes on each visit. Different motivations, or purposes, drive Jordanian students to create Facebook accounts. However, consistent with previous empirical findings, Facebook is being predominantly used for social and entertainment purposes (e.g., Hussain et al., 2012; Moradabadi et al., 2012; Nassar et al., 2013).

A growing number of Jordanian university students are using Facebook for academic purposes. This can be justified by the fact that many of students' university colleagues are actually their Facebook friends, and part of their encounter on Facebook would be about course related subjects, especially since they represent a common interest shared by students. Nevertheless, while Jordanian students seem to have found an educational use and potential in Facebook, such poten- 
tial is not fulfilled properly. When asked if they actually used Facebook for academic purposes, approximately three quarters ( $72 \%$ ) of Jordanian students indicated that they did. However, when asked about the frequency of such use, only $17.5 \%$ indicated that they were frequent users of Facebook for academic purposes. Such results suggest that there is a gap between what students embark on when they create a Facebook account and what they end up doing on it. This could be due to the lack of direction and adoption of Facebook in the teaching process by academics and universities. In other words, students seem to be willing to use Facebook for academic purposes, but without formal adoption and direction by universities, such potential will not materialize properly.

When asked about their attitudes towards the Formal application of Facebook for academic purposes, the majority of sampled students $(86.5 \%)$ considered it as a good method to be used. The majority of them believed that using Facebook for academic purposes would be a convenient and beneficial idea. Previous research (e.g., Al Doghmi et al., 2013) has indicated that Jordanian students have become more willing to acquire the benefits of Facebook capabilities such as sharing interactive discussion forums which enhanced flexibility in course content delivery. This paper has found that undergraduate university students preferred Facebook academic uses to be offered in a limited and suitable way so long as the focus was on administrative matters such as queries, lecture notes, and notices. In the same vein, and consistent with previous findings (e.g., Al-Atabi \& Younis, 2010; Eteokleous, Ktoridou, Stavrides, \& Michaelidis, 2012), students had an overall favorable attitude towards designing course-specific Facebook groups. Despite their modest agreement on the positive impact of such groups over their academic performance, students gave a strong support to other Facebook benefits, such as breaking barriers between students, facilitating information and knowledge sharing, improving teamwork and facilitating feedback. Interestingly, though, students strongly felt that participating in course-specific Facebook groups should be voluntary, which suggests that students still feel that Facebook is a free space for them and that it should not be restricted in any way or by any means. The fact that students gave low support to creating separate Facebook accounts for academic purposes further supports the previous argument. It also suggests that students considered learning as an integral part of their social lives which should not be isolated by separate Facebook accounts.

To conclude, the paper's findings came generally in line with previous empirical research underlining the growing tendency for students to use Facebook for academic purposes (e.g., Eteokleous et al., 2012; Hamat \& Embi, 2012). The results also contradicted with some earlier research underlining less favorable attitudes towards Facebook application for academic purposes (e.g., Hrastinski \& Aghaee, 2012; Haytko \& Parker, 2012). Such observations emphasize the importance of this paper's findings through underlining the fact that students' attitudes and actual application of Facebook for academic purpose is context dependent. In the particular context of Jordan, Facebook is being used as a social and academic platform by Jordanian students. They are motivated and willing to apply Facebook in their learning experience. Jordanian students are also accommodative of formal use of this method, but not in a restrictive manner. Students still want the freedom Facebook gives them, even when learning. Jordanian universities and academic institutions should seize such opportunity to improve students' learning experience. The application of Facebook, and perhaps other SNSs, in the teaching process could improve students' social and learning abilities and skills. However, such application should balance between the formality of academic encounter and the freedom and self-expression Facebook provides. Facebook feasibility as an efficient and exciting means of communication between students or with teachers could be used under certain cautions for supporting an academic community through either formal or informal ways. 


\section{Limitations and Future Research}

As underlined by previous research and most current figures, the majority of Jordanian university students use Facebook. Nevertheless little is known about how much, why, and how they use it. Furthermore, little is known about the potential of Facebook application in Jordanian students' learning process. This paper has attempted to shed more light on this area. Nevertheless, the paper has some limitations that can be addressed in future research. Firstly, our paper focused on students' use of Facebook only. Thus, the paper's findings cannot be generalized to students' uses of other types of SNSs. Future research should replicate our study be investigating other types of SNSs' applications among Jordanian students. Secondly, research population for this paper consisted of three Jordanian public universities only. This limits the generalizability of our findings to all Jordanian universities.

A more comprehensive research, including all public and private Jordanian universities should be able to yield more generalizable findings. Additionally, future research can also focus on perceptions of the tutors and members of teaching faculties, since they represent a major contributor to any formal Facebook learning endeavor. Thirdly, while most universities cultivate their own official Facebook pages, a future research avenue can focus on evaluating the effectiveness of such pages from users' point of view.

\section{References}

Ababneh, R. (2008). A comprehensive performance evaluation of the Jordanian customs department using the Balanced Scorecard. Jordan Journal of Business Administration, 4(4), 463-484.

Abu Husein, Al-H., Al-Sukkar, A., Salah, A., \& Jaradat, A. (2013).The impact of social network sites to determine student's orientations: Field study on Jordanian private universities. International Journal of Business, Humanities and Technology, 3(4), 61-68.

Abu Qudais, M., Al-Adhaileh, M., \& Al-Omari, A. (2010). Senior faculty members' attitudes in Jordanian universities towards using information and communication technology. International Arab Journal of e-Technology, 1(4), 135-141.

Abu-Shanab, E., \& Al-Tarawneh, H. (2013). How Jordanian youth perceive social networks influence. Computer Science and Information Technology, 1(2), 159-164.

Akyıldı,, M., \& Argan, M. (2012). Using online social networking: students' purposes of Facebook usage at the University of Turkey. Journal of Technology Research, 3. Available online at http://www.aabri.comwww.aabri.com/manuscripts/111085.pdf

Al Doghmi, A., Al-Shalabi, H., Jwaifell,M., Andraws, S., Awajan, A., \& Alrabea, A. I.(2013).The academic use of social networks among university students in Jordan. International Journal of Computer Science Issues, 10(5), 134-141.

Al Omoush , K.S., Yaseen ,S.G., \& Alma'aitah, M.A. (2012). The impact of Arab cultural values on online social networking: The case of Facebook. Computers in Human Behavior, 28, 2387-2399.

Al-Adwan, A., Al-Adwan, A. \& Smedley, J. (2013). Exploring students' acceptance of e-learning using Technology Acceptance Model in Jordanian universities. International Journal of Education and Development using Information and Communication Technology (IJEDICT), 9(2), 4-18.

Al-Atabi, M., \& Younis, O. (2010). Use of Facebook to support module delivery for undergraduate engineering programmes. Proceedings of the 2010 AAEE Conference, Sydney, Australia, 526-531.

Al-Debei, M. M., Al-Lozi, E., \& Papazafeiropoulou, A. (2013). Why people keep coming back to Facebook: Explaining and predicting continuance participation from an extended theory of planned behavior perspective. Decision Support Systems, 55(1), 43-54.

Alexa. (2013). Available at: http://www.alexa.com/topsites/countries/JO (Accessed January 18, 2013, May 20, 2013, August 10, 2013, and January 23, 2014). 
Allen, M. (2012). An education in Face book. Presentation at the RMIT Teaching and Learning Expo, 29 August 2012.Melbourne, Australia.

Al-Saleem, B. (2011). Language and identity in social networking sites. International Journal of Humanities and Social Science, 1(19), 197-202.

Arab Media Outlook. (2012), Arab Media Outlook 2011-2015 (Exposure and transition): Forecasts and analysis of traditional and digital media in the Arab world, Dubai Press Club, 2012. Retrieved February 11, 2013 from http://www.arabmediaforum.ae/userfiles/EnglishAMO.pdf

Arab Social Media Report. (2014, 24 November). Retrieved from http://www.arabsocialmediareport.com/News/index.aspx?PriMenuID=15\&mnu=Pri\#sthash.42c1QvKc .dpuf

Assi, R. (2011), Are women in Jordan empowered? No. TEDxDeadSea; Theme: Education, Creativity \& Entrepreneurship; Kempinski Hotel Ishtar-Dead Sea. Available at: http://www.tedxdeadsea.com/?p=1574.

Boyd, D., \& Ellison, N. B. (2008). Social network sites: Definition, history, and scholarship. Journal of Computer-Mediated Communication, 13(1), 210-230.

Cheung, C. M. K., Chiu, P. Y., \& Lee, M. K. O. (2011). Online social networks: Why do students use Facebook? Computers in Human Behavior, 27, 1337-1343.

DiVall, M. V., \& Kirwin, J. L. (2012). Using Facebook to facilitate course-related discussion between students and faculty members. American Journal of Pharmaceutical Education, 76(2), Article 32.

Estus, E. (2010). Using Facebook within a geriatric pharmacotherapy course. American Journal of Pharmaceutical Education, 74(8), Article 14.

Eteokleous, N., Ktoridou, D., Stavrides, I., \& Michaelidis, M. (2012). Facebook - A social networking tool for educational purpose: Developing special interest groups. International Conference on Information Communications Technology in Education (ICICTE). Rhodes, Greece, July 4 - 6, 2012. 363-375.

Facebook statistics. (2013, March). Key facts, Facebook newsroom. Retrieved May 19, 2012 and August 10, 2013 from http://newsroom.fb.com/Key-Facts

Gafni, R., \& Deri M. (2012). Costs and benefits of Facebook for undergraduate students. Interdisciplinary Journal of Information, Knowledge, and Management, 7, 45-61. Retrieved from http://www.ijikm.org/Volume7/IJIKMv7p045-061Gafni609.pdf

Gasaymeh, A., \& Jwaifell, M. (2013). A Study of Jordanian graduate students' attitudes toward and use of weblog in a blended learning course. Journal of Information Technology and Application in Education, 2(2), 67-79.

Grosseck, G., Bran, R., \& Tiru, L. (2011). Dear teacher, what should I write on my wall? A case study on academic uses of Facebook. Procedia Social and Behavioral Sciences, 15, 1425-1430.

Hamat, A., \& Embi, M.A. (2012). The use of social networking sites among Malaysian university students. International Education Studies, 5(3), 56-66.

Haneefa, M. K., \& Sumitha, E. (2011). Perception and use of social networking sites by the students of Calicut University. DESIDOC Journal of Library \& Information Technology, 31(4), 295-301.

Haytko, D. L., \& Parker, R. S. (2012). Social networking tools in a university setting: A students perspective. Journal of Instructional Pedagogies, 9, 1-9.

Hrastinski, S., \& Aghaee, N. M. (2012). How are campus students using social media to support their studies? An explorative interview study. Education and Information Technologies, 17(4), 451-464.

Hussain, I., Gulrez, N., \& Tahirkheli, S. H. (2012). Academic use of social media: Practices and problems of university students. International Conference on Education and Management Innovation IPEDR, 30,189-194, Singapore. 
Junco, R. (2012). The relationship between frequency of Facebook use, participation in Facebook activities, and student engagement. Computers \& Education, 58, 162-171.

Jwaifell, M., Al-Shalabi, H., Andraws, S., Awajan, A., \& Alrabea, A. (2013). The intensity of social networks group use among the students of Jordanian universities. Global Journal of Computer Science and Technology Network, Web \& Security, 13(2), 1-8.

Kalpidou, M., Costin, D., \& Morris, J. (2011). The relationship between Facebook and the well-being of undergraduate college students. Cyber psychology, Behavior, and Social Networking, 14, 183-189.

Karl, K., \& Peluchette, J. V. (2011). "Friending" professors, parents and bosses: A Facebook connection conundrum. Journal of Education for Business, 86(4), 214-222.

Kassem, M. (2013). Facebook as a nation-wide civic education classroom listening to the voices of Egyptian secondary school students. Journal of Emerging Trends in Educational Research and Policy Studies, 4(5), 771-785.

Kayri, M., \& Çakır, Ö. (2010). An applied study on educational use of Facebook as a web 2.0 tool: The sample lesson of computer networks and communication. International Journal of Computer Science \& Information Technology (IJCSIT), 2(4), 48-58.

Khasawneh, M., \& Ibrahim, H. (2012). A model for adoption of ICT in Jordanian higher education institutions: An empirical study. Journal of e-Learning \& Higher Education, 2012, Article ID 877178. Retrieved from http://www.ibimapublishing.com/journals/JELHE/2012/877178/877178.pdf

Liu, Y. (2010). Social media tools as a learning resource. Journal of Educational Technology Development and Exchange, 3(1), 101-114.

Madge, C., Meek, J., Wellens, J., \& Hooley, T. (2009). Facebook, social integration and informal learning at university: 'It is more for socialising and talking to friends about work than for actually doing work'. Learning, Media \& Technology, 34(2), 141-155.

Mazman, S. G., \& Usluel, Y. K. (2010). Modeling educational usage of Facebook. Computers \& Education, 55, 444-53.

Ministry of higher education and scientific research, Jordan (2013). Available at http://www.mohe.gov.jo /Statistics/tabid/69/language/ar-JO/Default.aspx

Moradabadi, Y. N., Gharehshiran, M. A., \&Amrai, K. (2012). What is the motivation student of Iranians for using Facebook? Procedia - Social and Behavioral Sciences, 46, 5192 -5195.

Nadkarni, A., \& Hofmann, S. G. (2012).Why do people use Facebook? Personality and Individual Differences, 52, 243-249.

Nassar, I. A, Hayajneh, J. A, \& Almsafir, M. K. H. (2013). Relation between social network and da'wah to Islam: A case study on Jordanian students. International Journal on Islamic Applications in Computer Science and Technology, 1(1), 9-18.

Ophus, J. D., \& Abbitt, J.T. (2009). Exploring the potential perceptions of social networking systems in university courses. Journal of Online Learning and Teaching (MERLOT), 5(4), 639-648.

Pempek, T., Yermolayeva, Y., \& Calvert, S. L. (2009). College students' social networking experiences on Facebook. Journal of Applied Developmental Psychology, 30(3), 227-238.

Petrović, N., Petrović, D., Jeremić, V., Milenković, N., \& Ćirović., M. (2012). Possible educational use of Facebook in higher environmental education. ICICTE, 355-262.

Roblyer, M. D., McDaniel, M., Webb, M., Herman, J., \& Witty, J. V. (2010). Findings on Facebook in higher education: A comparison of college faculty and student uses and perceptions of social networking sites. The Internet and Higher Education, 13(3), 134-140.

Ruleman, A. B. (2012).Social media at the university: A demographic comparison. New Library World, $113(7 / 8), 316-332$. 
Sekaran, U., \& Bougie, R. (2010). Research methods for business: A skill building approach (5th ed.)., John Wiley \& Sons, Inc.

Selwyn, N. (2009). Faceworking: Exploring students' education-related use of Facebook. Learning, Media and Technology, 34(2), 157-174.

Smith, S. D., \& Caruso, J. B. (2010). The ECAR study of undergraduate students and information technology. EDUCAUSE Center for Applied Research, Boulder, CO. Available at:

http://net.educause.edu/ir/library/pdf/ers1006/rs/ers1006w.pdf.

Socialbakers. (2013). Accessed January 27, 2014 from http://www.socialbakers.com/blog/1594-march2013-social-media-report-facebook-pages-in-jordan

Swidan, A., Al-Shalabi, H., Jwaifell, M., Awajan, A., \& Alrabea, A. (2013). The intensity and the factors affecting the use of social network sites among the students of Jordanian universities. International Journal of Computer Science Issues, 10(1), 492-498.

Tiryakioglu, F., \& Erzurum, F. (2011). Use of social networks as an education tool. Contemporary Educational Technology, 2(2), 135-15

\section{Appendix: Questionnaire Measurements and Items}

\begin{tabular}{|c|c|c|}
\hline \multicolumn{3}{|c|}{ Parts, Sections, Measurements and Items } \\
\hline \multicolumn{3}{|c|}{ Part Two: Facebook Experience } \\
\hline \multicolumn{2}{|r|}{\begin{tabular}{rrr|} 
Face book membership duration ,Frequency of visits \& Length & .1 \\
of stay in face book & \\
\end{tabular}} & References \\
\hline Q5 & How many active face book accounts do you have? & \multirow{5}{*}{$\begin{array}{l}\text { Abu Husein et al., 2013; } \\
\text { Aky1ldı \&Argan, 2012; } \\
\text { Gafni \& Deri, 2012; } \\
\text { Swidan et al., 2013; } \\
\text { Nassar et al., 2013. }\end{array}$} \\
\hline Q6 & $\begin{array}{l}\text { Next to Face book, what other social networking site do you have } \\
\text { account on? }\end{array}$ & \\
\hline Q7 & $\begin{array}{l}\text { How long have you been a Face book user? Approximately how long } \\
\text { have you had your Face book profile? }\end{array}$ & \\
\hline Q8 & In general, How many times do you check your face book account? & \\
\hline Q9 & On average, how long do you spend on Face book per a visit? & \\
\hline \multicolumn{2}{|r|}{$\begin{array}{lll} & \text { Motivations for Using Facebook } \quad .2 \\
\end{array}$} & References \\
\hline Q1 & $\begin{array}{l}\text { Staying in touch with my friends/family and connecting with people I } \\
\text { have lost touch with }\end{array}$ & \multirow{8}{*}{$\begin{array}{l}\text { Abu Husein et al., 2013; } \\
\text { Akyıldı \& Argan, 2012; } \\
\text { Hrastinski \& Aghaee, } \\
\text { 2012; } \\
\text { Nassar et al., 2013; } \\
\text { Roblyer et al., 2010. }\end{array}$} \\
\hline Q2 & Entertainment, having fun and wasting time & \\
\hline Q3 & $\begin{array}{l}\text { General academic purposes(such as sharing information about my } \\
\text { courses) }\end{array}$ & \\
\hline Q4 & Meeting new people and making new relationships & \\
\hline Q5 & $\begin{array}{l}\text { Self-presentation and letting others know what is happening in my } \\
\text { life }\end{array}$ & \\
\hline Q6 & $\begin{array}{l}\text { Supporting worthy causes (political, environmental, religious, nation- } \\
\text { al, medical, etc.) }\end{array}$ & \\
\hline Q7 & $\begin{array}{l}\text { Expressing my opinions and views since I can say on Facebook what } \\
\text { I can't in person }\end{array}$ & \\
\hline Q8 & $\begin{array}{l}\text { Meeting or forming relationships with opposite gender (not necessari- } \\
\text { ly romantic) }\end{array}$ & \\
\hline
\end{tabular}




\begin{tabular}{|c|c|c|}
\hline & Facebook Activities and their Frequencies & References \\
\hline Q1 & Viewing and reading my friends participations & \multirow{12}{*}{$\begin{array}{l}\text { Gafni \& Deri, 2012; } \\
\text { Hrastinski \& Aghaee, } \\
\text { 2012; Hussain et al. } 2012\end{array}$} \\
\hline Q2 & Updates my status and posting on my wall. & \\
\hline Q3 & Commenting on my friends updates & \\
\hline Q4 & Face book chatting. & \\
\hline Q5 & Playing Face book games. & \\
\hline Q6 & Uploading photos. & \\
\hline Q7 & Uploading videos. & \\
\hline Q8 & Tagging subjects, news, videos and photos. & \\
\hline Q9 & Sending private messages. & \\
\hline Q10 & Viewing and checking pages. & \\
\hline Q11 & Interacting with groups. & \\
\hline Q12 & $\begin{array}{l}\text { Discussing, collaborating, and getting help about my courses matters } \\
\text { and lectures. }\end{array}$ & \\
\hline \multicolumn{3}{|c|}{ Part Three: Facebook and Formal Academic Purposes } \\
\hline \multicolumn{2}{|r|}{ Students' Perceptions about Formal Academic Facebook Use $\quad .1$} & References \\
\hline Q1 & $\begin{array}{l}\text { In general, How do you perceive using face book for academic or } \\
\text { educational purposes? }\end{array}$ & Roblyer et al., 2010. \\
\hline \multicolumn{2}{|r|}{ Students' Perceptions about Course-Specific "Facebook Groups" $\quad .2$} & References \\
\hline Q1 & $\begin{array}{l}\text { It's a good idea to create closed Facebook group to share course ma- } \\
\text { terial, such as assignment, study tips, questions, etc. }\end{array}$ & \multirow{14}{*}{$\begin{array}{l}\text { Al-Atabi \& Younis, } \\
\text { 2010; Al Doghmi et al., } \\
\text { 2013; Allen, 2012; Di- } \\
\text { Vall \& Kirwin, 2012; } \\
\text { Estus, 2010; Eteokleous } \\
\text { et al., 2012; Grosseck et } \\
\text { al., 2011; Liu, 2010; } \\
\text { Ophus \& Abbitt, 2009; } \\
\text { Roblyer et al., 2010. }\end{array}$} \\
\hline Q2 & $\begin{array}{l}\text { Facebook groups, in general, are useful method for academic and } \\
\text { educational purposes. }\end{array}$ & \\
\hline Q3 & $\begin{array}{l}\text { An academic group is a comfortable learning method because it is not } \\
\text { necessary for me and lecturers or other class students to become } \\
\text { "friends". }\end{array}$ & \\
\hline Q4 & $\begin{array}{l}\text { Facebook familiarity, and frequently use, could encourage students to } \\
\text { join and discuss learning material on specific Facebook groups }\end{array}$ & \\
\hline Q5 & $\begin{array}{l}\text { I will create a separate Facebook account for my courses, because I } \\
\text { don't like my lecturers or my class mates to see my original profile. }\end{array}$ & \\
\hline Q6 & Joining “specific-course Facebook group" should be voluntary. & \\
\hline Q7 & $\begin{array}{l}\text { A Facebook group is a convenient mean to facilitate student engage- } \\
\text { ment and participation in teamwork }\end{array}$ & \\
\hline Q8 & $\begin{array}{l}\text { Group administration should be left basically with the students, lec- } \\
\text { turers interferences should be for committing or adding relative links } \\
\text { or topics. }\end{array}$ & \\
\hline Q9 & A Facebook learning group should be just an academic group & \\
\hline Q10 & $\begin{array}{l}\text { A Facebook learning group could break barriers for those who are } \\
\text { shy to find help, and it could encourage students to freely ask ques- } \\
\text { tions and speak }\end{array}$ & \\
\hline Q11 & $\begin{array}{l}\text { In a Facebook group, tutors can get more feedback than in traditional } \\
\text { class situations, where a few students may participate. }\end{array}$ & \\
\hline Q12 & $\begin{array}{l}\text { An academic Facebook group could be valuable for me, saving my } \\
\text { effort and time }\end{array}$ & \\
\hline Q13 & $\begin{array}{l}\text { I intended to join specific- course Facebook group for my courses if it } \\
\text { applied }\end{array}$ & \\
\hline Q14 & $\begin{array}{l}\text { My grades would be better if I participated in course-specific Face- } \\
\text { book group. }\end{array}$ & \\
\hline
\end{tabular}




\section{Biographies}

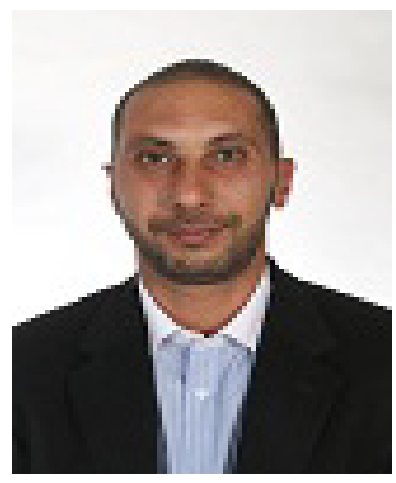

Ayman Alarabiat is a PhD student in Information Systems and Technology Department at the University of Minho, Portugal. He received his MBA degree in Electronic Business from Mutah University, Jordan. Ayman's research interests include E-participation, Egovernment, web-based human computer interaction, and social media.

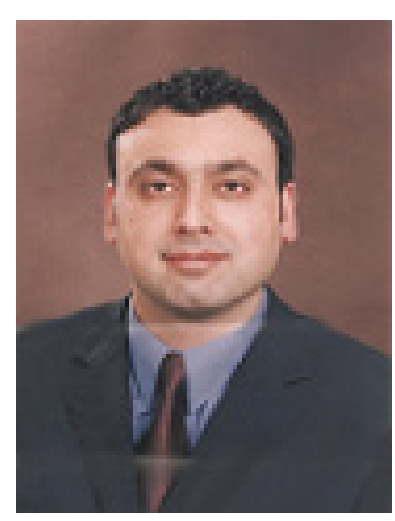

Samer M. Al-Mohammad is an Associate Professor of Marketing at the Faculty of Business Administration, Mutah University, Jordan. Dr Al-Mohammad holds an MBA and a PhD in Marketing from the University of Huddersfield. His research interests pertain to Marketing information systems, Marketing knowledge, user technology adoption, and consumer behavior. Samer's articles have appeared in various refereed journals. 